\title{
Effect of the seed coat on dormancy and germination in Stylosanthes humilis H. B. K. seeds ${ }^{1}$
}

\author{
Izabel de Souza Chaves ${ }^{2}$, Nilo Cesar Queiroga Silva², Dimas Mendes Ribeiro
}

\begin{abstract}
Seed of Townsville stylo (Stylosanthes humilis H.B.K.) is known to exhibit a hard seed coat and when freshly harvested also show a physiological dormancy, however, the nature of the co-actions between seed coat and embryo growth that determine dormancy is poorly understood. In this study, physical dormancy of Townsville stylo seeds was not reduced during natural ageing at room temperature, in contrast to the physiological dormancy, which is gradually overcome during after-ripening. Furthermore, the permeability of seed coat was affected by scarification treatments as well as by low-pH solutions. Together, these data indicate that physical dormancy overcome of seed is prerequisite for radicle protrusion and physiological dormancy of Townsville stylo seeds contribute to its timing.
\end{abstract}

Index terms: physical dormancy, physiological dormancy, Townsville stylo.

\section{Efeito do tegumento na dormência e na germinação de sementes de Stylosanthes humilis H. B. K.}

\begin{abstract}
RESUMO - Semente de estilosantes (Stylosanthes humilis H.B.K.) é conhecida por apresentar tegumento rijo e quando recém colhida também exibe dormência fisiológica, entretanto, a natureza da coação entre o tegumento e o crescimento do embrião que determina a sua dormência é pouco conhecida. Nesse estudo, a dormência física de sementes de estilosantes não foi reduzida durante o envelhecimento natural à temperatura ambiente, em contraste com a dormência fisiológica que foi superada gradualmente durante o envelhecimento pós-colheita. Além disso, a permeabilidade do tegumento foi afetada por tratamentos de escarificação bem como por soluções de baixo pH. Juntos, esses resultados indicam que a superação da dormência física da semente é um pré-requisito para a protrusão da radícula e a dormência fisiológica das sementes de estilosantes contribui para temporização da germinação.
\end{abstract}

Termo para indexação: dormência física, dormência fisiológica, estilosante.

\section{Introduction}

Townsville stylo (Stylosanthes humilis H.B.K.) is an annual forage legume common in natural pastures of tropical America (Williams et al., 1984; Stappen et al., 2000; SantosGarcia et al., 2012). The species is utilizing for pasture improvement in tropical zones due to its high-quality forage for livestock, high seed production, and wide adaptability to low fertility soils (Edye, 1987). In addition, Stylosanthes are potentially useful species aiming at ecological purposes, such as rehabilitation of damaged ecosystems (Grigg et al., 2000; Starr et al., 2013). Seeds of Townsville stylo exhibit a physiological dormancy, which is gradually lost upon post-harvest ageing. Following harvesting physiological dormancy is lost very slowly; by six months germination increases substantially, and 12-15 after harvest seeds placed under a $30 / 25{ }^{\circ} \mathrm{C}$ day/night cycle with $60 / 70 \%$ relative humidity showed full germination (Vieira and Barros, 1994). Any stressing factor such as low $\mathrm{pH}$ solutions (Pelacani et al., 2005a,b), selenium compounds (Pinheiro et al., 2008) and ferric ions (Ribeiro et al., 2011), which induced ethylene production by seeds, promotes the overcome of physiological dormancy of S. humilis seeds. As with some other legumes such as Senna multijuga (Rodrigues-Junior et al., 2014) Cassia

${ }^{1}$ Submitted on 08/11/2016. Accepted for publication on 04/24/2017.

${ }^{2}$ Departamento de Biologia Vegetal, Universidade Federal de Viçosa, 36570-900 - Viçosa, MG, Brasil.

*Corresponding author<izabelchaves@yahoo.com.br> 
leptophylla and Senna macranthera (Paula et al., 2012), seeds of Townsville stylo also exhibit physical dormancy, resulting from an impermeable seed coat (Smýkal et al., 2014).

The seed coat exerts its germination-restrictive action most of the time by being impermeable to water and/ or oxygen or by its mechanical resistance to radicle protrusion (Linkies et al., 2009; Smýkal et al., 2014). In legumes, a densely packed layer of palisade cells impregnated with water-repellent compounds causes mechanical resistance of seed coat (Baskin and Baskin, 2004; Smýkal et al., 2014, Baskin and Baskin, 2014). The seed becomes permeable to water only when the coat is disrupted in some way, particularly at the lens (strophiole) region, which is usually the physically weakest part of the seed coat (Moïse et al., 2005; Jaganathan et al., 2017). Thus, in the absence of physiological dormancy, overcoming of physical dormancy may lead to immediate germination of the seeds upon imbibition. Despite of the known association between seed coat permeability and embryonic growth potential, the nature of the co-actions between seed coat and embryo growth that determine dormancy is still unclear.

A wide range of factors that may potentially disrupt seedcoat imposed dormancy under natural conditions have been identified, with differing implications for seed bank dynamics and seedling emergence patterns (Van Klinken et al., 2006; Gama-Arachchige et al., 2012). For example, high temperatures promoted dormancy overcome in impermeable seeds of $S$. humilis and S. hamata during the hot, dry season in northern Australia (McKeon and Mott, 1982). Mechanical abrasion by soil particle, decomposition of the seed coat by microbial action as well as smoke or heat shock from fire are the others possible environment factors affecting physical dormancy of seeds in nature (Briggs and Morris, 2008). A strong positive relationship between acidic solutions (low $\mathrm{pH}$ ) and overcome of physiological dormancy has been found in scarified seeds of S. humilis (Pelacani et al., 2005a,b; Ribeiro et al., 2010). However, the importance of low $\mathrm{pH}$ for dormancy overcome in intact seeds of $S$. humilis has been poorly explored. Thus, the aim of the present study was to analyse the consequence of seed-coat-imposed dormancy on the physiological dormancy and germination of S. humilis seeds.

\section{Material and Methods}

\section{Plant material and germination assays}

Plants of S. humilis H.B.K. were grown in 3.0 L plastic pots in a greenhouse in Viçosa $\left(20^{\circ} 45^{\prime} \mathrm{S}, 42^{\circ} 15^{\prime} \mathrm{W}\right)$, Minas Gerais, Brazil. Matures pods were harvested and stored in paper bags in laboratory at $30 / 25{ }^{\circ} \mathrm{C}$ day/night cycle with $60 / 70 \%$ relative humidity for $1,6,12,24,36$ and 48 months prior to extraction from the pods. In this way, six seed lots (with different natural ageing time) were used for germination experiments. Following dehusking, intact seeds or mechanically (scarification with fine sandpaper number 150 ) and chemically (immersion in $\mathrm{H}_{2} \mathrm{SO}_{4} 98 \%$ for 1 or 5 min and subsequent washing in water) treated seeds were sterilized with $0.5 \% \mathrm{NaOCl}$ for $10 \mathrm{~min}$ and thoroughly washed with distilled water. Seeds (intact or scarified) were placed in glass Petri-dishes $90 \mathrm{~mm}$ diameter containing two layers of Whatman $\mathrm{n}^{\circ} 1$ filter paper moistened with $10 \mathrm{~mL}$ water (control), 1-aminocyclopropane-1-carboxylic acid (ACC), the biochemical precursor of ethylene, or 2-choroethylphosphonic acid (CEPA), an ethylene-releasing compound. To further evaluate the role of ethylene in seed germination, intact seeds were placed in $50 \mathrm{~mL}$ Erlenmeyer flasks containing two layers of Whatman $\mathrm{n}^{\circ} 1$ filter paper moistened with $10 \mathrm{~mL}$ of water. Erlenmeyer flasks were immediately sealed with serum rubber caps and ethylene (to attain $10 \mu \mathrm{M}$ ) was injected in sealed flasks. The atmosphere of flasks was occasionally stirred with a syringe with needle inserted through the rubber seal. The effects of low $\mathrm{pH}$ solution on the mechanism of seed germination were also examined by treating seeds (intact or mechanically scarified with sand paper) with $10 \mathrm{~mL}$ MacIlvaine $(10 \mathrm{mM})$ buffer solution at $\mathrm{pH}$ 4.0-7.0 in glass Petri-dishes $90 \mathrm{~mm}$ diameter containing two layers of Whatman $n^{\circ} 1$ filter paper. Petridishes and Erlenmeyer flasks containing fifty seeds were placed in the dark in a day/night growth chamber (Forma Scientific Inc., Ohio, USA) at $30^{\circ} \mathrm{C}$. The seed was considered as germinated upon protrusion of its radicle.

\section{Seed coat permeability assay using tetrazolium staining}

Entire seeds were incubated in a $1 \%(\mathrm{w} / \mathrm{v})$ solution of 2 , 3, 5-triphenyltetrazolium chloride (Sigma-Aldrich) at $30^{\circ} \mathrm{C}$ in darkness for $5 \mathrm{~d}$ as described by Wharton (1955). The embryo and cotyledons of Townsville stylo seeds stain red upon entry of the tetrazolium salt solution in the viable seed, but stay whitish when the dye does not penetrate. Thus, enhanced staining intensity indicates enhanced seed coat permeability (Debeaujon et al., 2000).

\section{Microscopy}

We performed microscopic analysis of mature seed coat to correlate the germination behaviour of Townsville stylo seeds with precise seed coat characteristics. Two treatments were compared for their effectiveness in overcoming hard seed coat dormancy (i) manual scarification - seeds were subject to manual scarification by gently rubbing between fine sand paper ( $\left.n^{\circ} 150\right)$ for $1 \mathrm{~min}$, (ii) chemical scarification 
- seeds were immersed in $20 \mathrm{~mL}$ of $98 \% \mathrm{H}_{2} \mathrm{SO}_{4}$ for $1 \mathrm{~min}$ or $5 \mathrm{~min}$ at ambient temperature $\left(\sim 25{ }^{\circ} \mathrm{C}\right)$. The seeds were then washed thoroughly under running water for $5 \mathrm{~min}$. Seeds were mounted directly on double-sided adhesive tape affixed to scanning electron microscopy stubs. Then, the samples were coated with gold-palladium $(15 \mathrm{~nm})$ in a sputter coater and examined using a scanning electron microscope (LEO; EVO 50 XVP, Cambridge, UK).

\section{Statistical analysis}

The statistical design of the assays was based on a completely randomized distribution with five replicates with 50 seeds each for germination test in Petri-dishes or Erlenmeyer flasks. Germination percentage was transformed to arcsin $(\% \mathrm{G} / 100)^{1 / 2}$, prior to analysis and all data were checked for normality. Analysis of variance (ANOVA; $p<0.05$ ) was carried out to determine effects of treatments. If ANOVA showed significant effects, Tukey test was used to determine differences among treatments. All mean comparisons were performed with SPSS (Statistical Package for the Social Sciences) 11.0 for Windows Statistical Software Package.

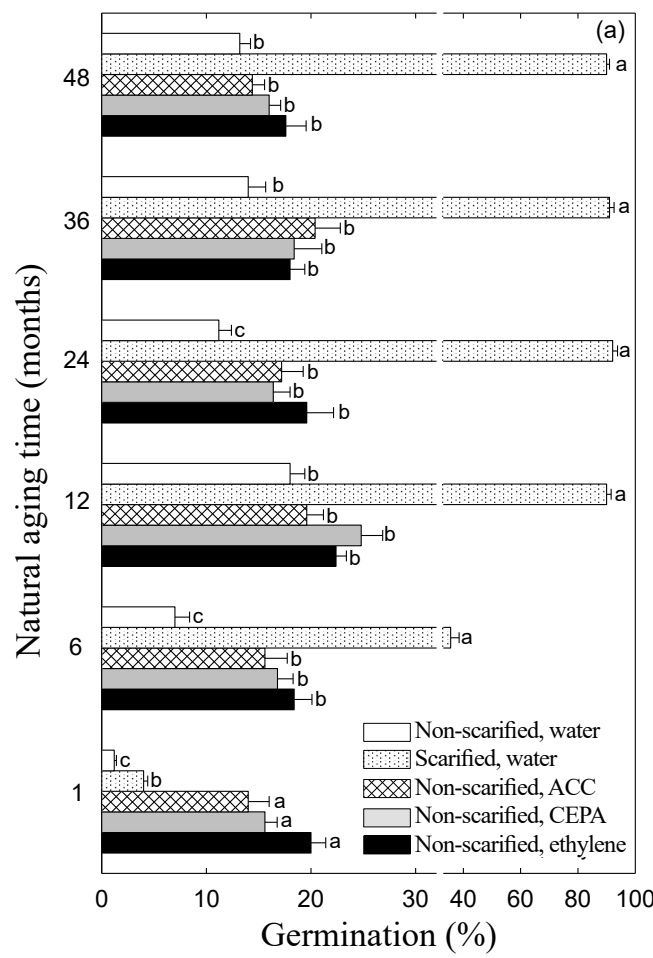

\section{Results and Discussion}

The degree of dormancy of Townsville stylo seeds was assessed by determining the germination percentage of the seed lots with different post-harvest age (Figure 1a). After mechanical scarification of the seeds, freshly harvested seeds of Townsville stylo were dormant, but this physiological dormancy has disappeared after 12 months after-ripening (Figure 1a). This agreed with the suggestion of Vieira and Barros (1994) that, for Townsville stylo seeds, a dry storage for up to 1 year would be required for the enhancement of germination. However, compared with freshly harvested seeds, the non-dormant seeds displayed a similar permeability of seed coat, demonstrating that natural ageing time did not increase permeability of Townsville stylo seeds to tetrazolium solution (Figure 1b). Cell expansion growth required for radicle protrusion and seed coat rupture depends on environmentally and hormonally regulated cell wall-loosening mechanisms (Van Sandt et al., 2007; Linkies et al., 2009; Muller et al., 2009; Morris et al., 2011). In Townsville stylo embryo hypocotylradicle axis growth are associated with ethylene production

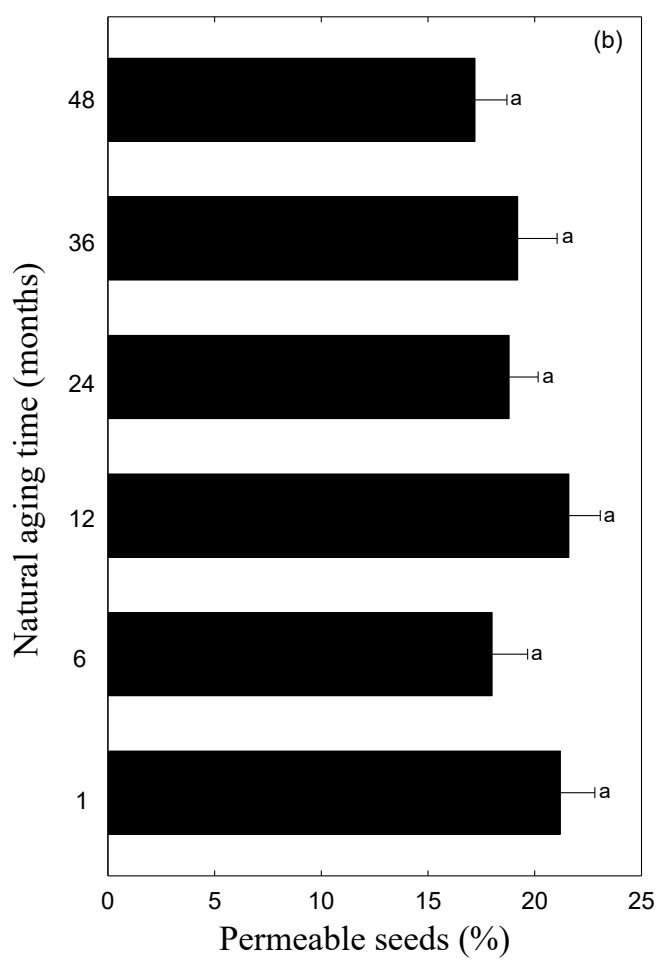

Figure 1. Effect of dry storage on dormancy release of Townsville stylo seeds. (a) Germination was determined in mechanically scarified seeds imbibed just in water or in intact seeds treated with ACC (1 mM), CEPA (1 mM) and ethylene gas $(10 \mu \mathrm{M})$. (b) Permeability of intact seeds to tetrazolium solution. Remaining fraction of seed to $100 \%$ corresponds to impermeable seeds. Germination and permeability of seeds to tetrazolium salt were carried out on the $5^{\text {th }}$ day. Values with the same letter within (a) each natural aging time and (b) among natural aging time are not statistically different at the $5 \%$ level by Tukey test. Data points are means of five replicates \pm standard error. 
as a mechanism for cell expansion growth (Vieira and Barros, 1994; Ribeiro and Barros, 2006). Freshly harvested seed and non-dormant seeds germinated only about $20 \%$ when treated with ACC (immediate precursor of ethylene), CEPA (an ethylene-releasing compound) or ethylene gas (Figure 1a). The observation that intact seeds were permeable to tetrazolium salt solution in a manner related to germination behaviour of seeds treated with ACC, CEPA or ethylene gas demonstrates that seed coat play a major role on the imposition of germination of Townsville stylo seeds and that seed coat weakening is not the consequence of ethylene action. Therefore, ethylene requirement for physiological dormancy alleviation as well as for germination of Townsville stylo seed appears to be under control of physical dormancy imposed by the hard seed coat. The hardseededness and water impermeability of many legume seeds is due to a palisade epidermal layer of thick-walled Malphighian cells in the outer testa (Moïse et al., 2005). Thus, the germination behaviour of intact seeds of Townville stylo can be related with structure of the seed coat: a cuticle and a palisade layer composing the outer integument followed by an endothelium layer and a crushed parenchymatic layer forming the inner integument (Figures 2a-d).

The important restrictive role of the seed coat in the germination of Townsville stylo seeds was supported further by scarification experiments. It is known that physical and chemical scarification overcome physical dormancy of Stylosanthes seeds (Mott and Mckeon, 1979; Anand et al., 2011). In this context, seed coat permeability to tetrazolium salt solution was increased in dormant and non-dormant seeds scarified with sand paper or treated with $\mathrm{H}_{2} \mathrm{SO}_{4}$ (Table 1). However, scarification treatments increased germination of non-dormant seeds i.e., seeds without physiological dormancy, but not in seeds with physiological

Table 1. Permeability of Townsville stylo seed coat to tetrazolium solution and germination of dormant (15 post-harvest days old) and non-dormant (765 post-harvest days old) seeds after treatment with different physical dormancy breaking methods. Permeability of seeds and germination were carried out on the 5 th day.

\begin{tabular}{|c|c|c|}
\hline Treatment & $\begin{array}{l}\text { Permeable seed } \\
\text { fraction }(\%)\end{array}$ & Germination (\%) \\
\hline \multicolumn{3}{|c|}{ Dormant seed } \\
\hline Non-scarified (Control) & $20.4 \pm 1.3 \mathrm{c}$ & $2.9 \pm 0.7 \mathrm{a}$ \\
\hline Mechanical scarification & $98.8 \pm 1.2 \mathrm{a}$ & $3.4 \pm 0.9 \mathrm{a}$ \\
\hline $\begin{array}{c}\text { Chemical scarification - } \\
1 \mathrm{~min}_{2} \mathrm{SO}_{4}\end{array}$ & $74.8 \pm 3.0 \mathrm{~b}$ & $3.1 \pm 0.5 \mathrm{a}$ \\
\hline $5 \mathrm{~min} \mathrm{H}_{2} \mathrm{SO}_{4}$ & $97.6 \pm 1.0 \mathrm{a}$ & $4.0 \pm 1.0 \mathrm{a}$ \\
\hline \multicolumn{3}{|c|}{ Non-dormant seed } \\
\hline Non-scarified (Control) & $18.8 \pm 2.1 \mathrm{c}$ & $16.4 \pm 1.5 \mathrm{c}$ \\
\hline Mechanical scarification & $98.8 \pm 0.8 \mathrm{a}$ & $94.0 \pm 2.1 \mathrm{a}$ \\
\hline $\begin{array}{c}\text { Chemical scarification - } \\
1 \mathrm{~min}_{2} \mathrm{SO}_{4}\end{array}$ & $77.2 \pm 3.1 \mathrm{~b}$ & $74.4 \pm 4.7 \mathrm{~b}$ \\
\hline $5 \min _{2} \mathrm{SO}_{4}$ & $99.2 \pm 0.8 \mathrm{a}$ & $94.4 \pm 2.6 \mathrm{a}$ \\
\hline
\end{tabular}

In each column, means do not differ significantly at the $5 \%$ level by Tukey test, when followed by the same letter. Data are means \pm standard error of five replicates.
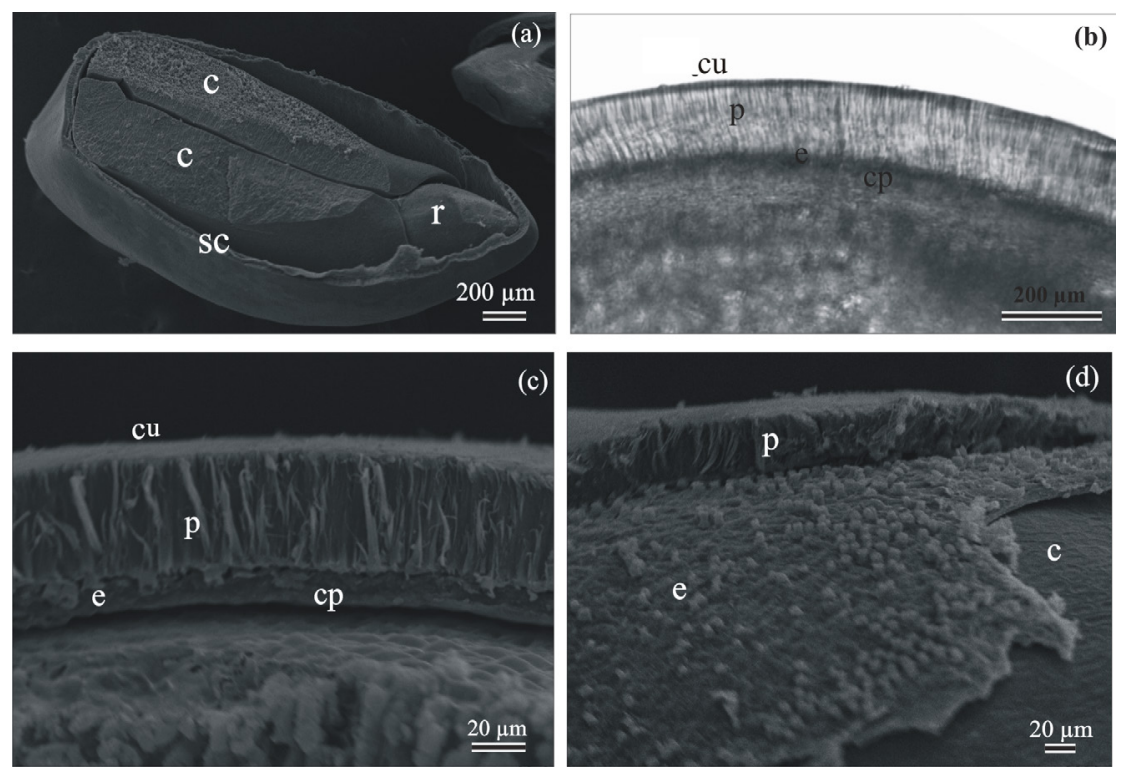

Figure 2. Scanning electron micrographs of Townsville stylo seed. (a) Entire mature seeds (15 post-harvest days old) showing radicle tip (r), cotyledons (c) and seed coat (sc). (b,c and d) Structure of the seed coat showing cuticle (cu), palisade layer (p), endothelium layer (e), crushed parenchymatic layer (cp) and cotyledons (c). 
dormancy (Table 1). Scanning electron micrographs revealed that the surface of mechanically scarified seeds peeled at various places, resulting in a weakening of the seeds coat (Figure $3 b)$. In contrast, scarification with $\mathrm{H}_{2} \mathrm{SO}_{4}$ overcame physical dormancy of seeds by causing many randomly located cracks in the seed coat, which than act as sites of water entry (Figures $3 \mathrm{c}-\mathrm{g}$ ). However, germination of freshly harvested seed was not increased after scarification treatments (Figures 4a, e), indicating that Townsville stylo seeds depend on a stepwise physiological dormancy-overcoming behaviour in timing their germination. In agreement with this, scarified dormantseeds were able to germinate quite rapidly when imbibed in CEPA (Figure 4c), an ethylene-releasing compound. On the other hand, mechanical or chemical scarification of aged Townville stylo seeds can be substitute for the exogenous CEPA requirement for germination (Figures 4d, f). Together, these data indicate that physical dormancy overcome is prerequisite for radicle protrusion and physiological dormancy of Townsville stylo seeds contribute to its timing.

In many ecosystems, soil moisture and temperature are the two most important factors that determine seasonal germination pattern and modulate persistence and dormancy of soil seed banks (Benech-Arnold et al., 2000; Walck et al., 2005; Batlla and Benech-Arnold, 2010). For example, McKeon and Mott (1982) showed that seeds of S. humilis and S. hamata were softened by temperature fluctuation during the
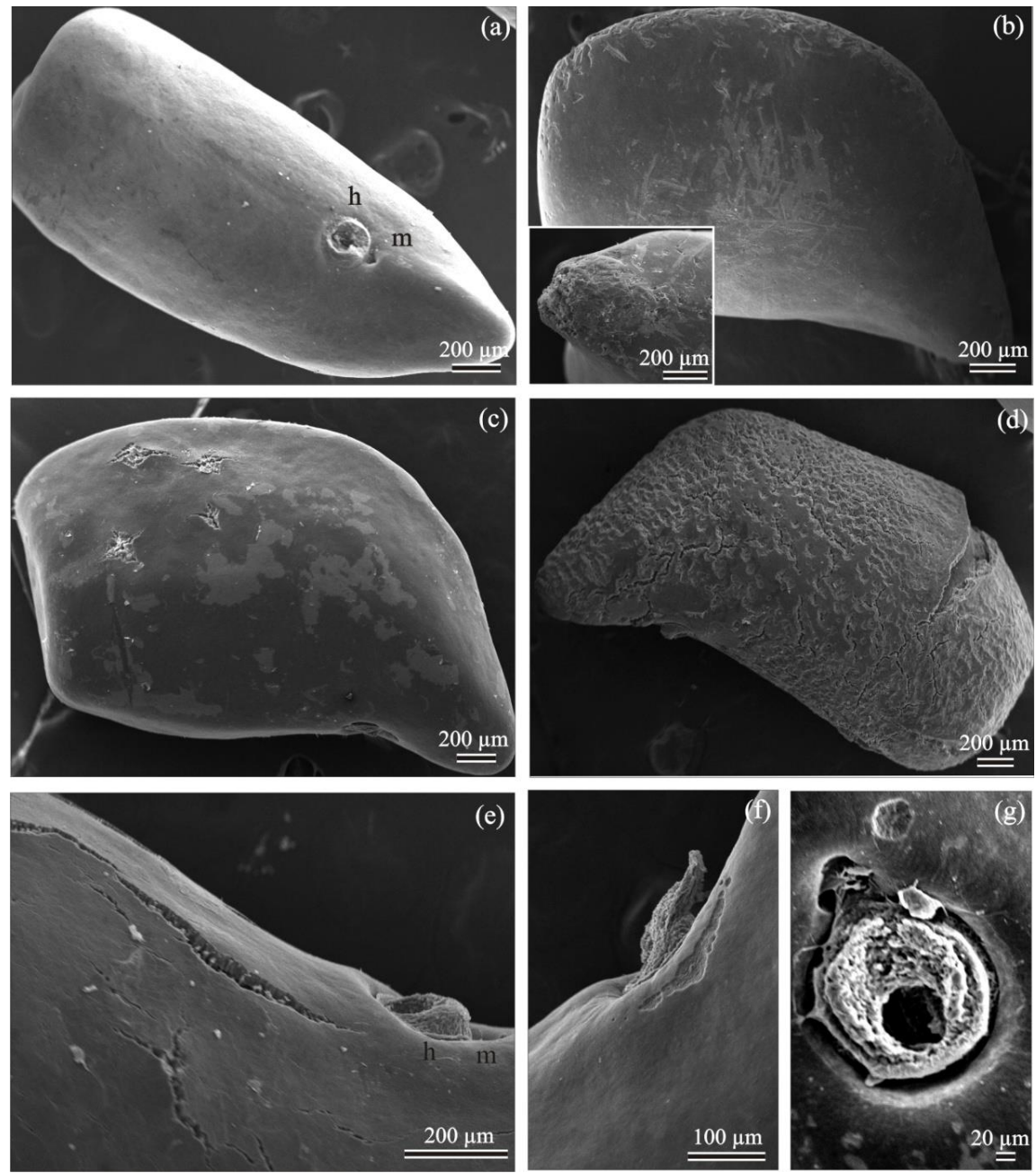

Figure 3. Scanning electron micrographs of Townsville stylo seed coat after pre-treatment with different dormancy breaking methods. (a) Intact seeds (15 post-harvest days old) showing hilum (h) and micropyle (m); (b) mechanical scarification with fine sand paper. Detail shown the damage caused by sandpaper occurs preferentially in the curved region and at the extremity where the protrusion of the radicle occurs; (c and d) acid scarification with $\mathrm{H}_{2} \mathrm{SO}_{4}$ for 1 and 5 min, respectively. (e) Cracks are see on the surface of seeds treated with $\mathrm{H}_{2} \mathrm{SO}_{4}$ for $1 \mathrm{~min}$. (f and g) Morphology of the hilum area after treatment with $\mathrm{H}_{2} \mathrm{SO}_{4}$ for 5 min. 

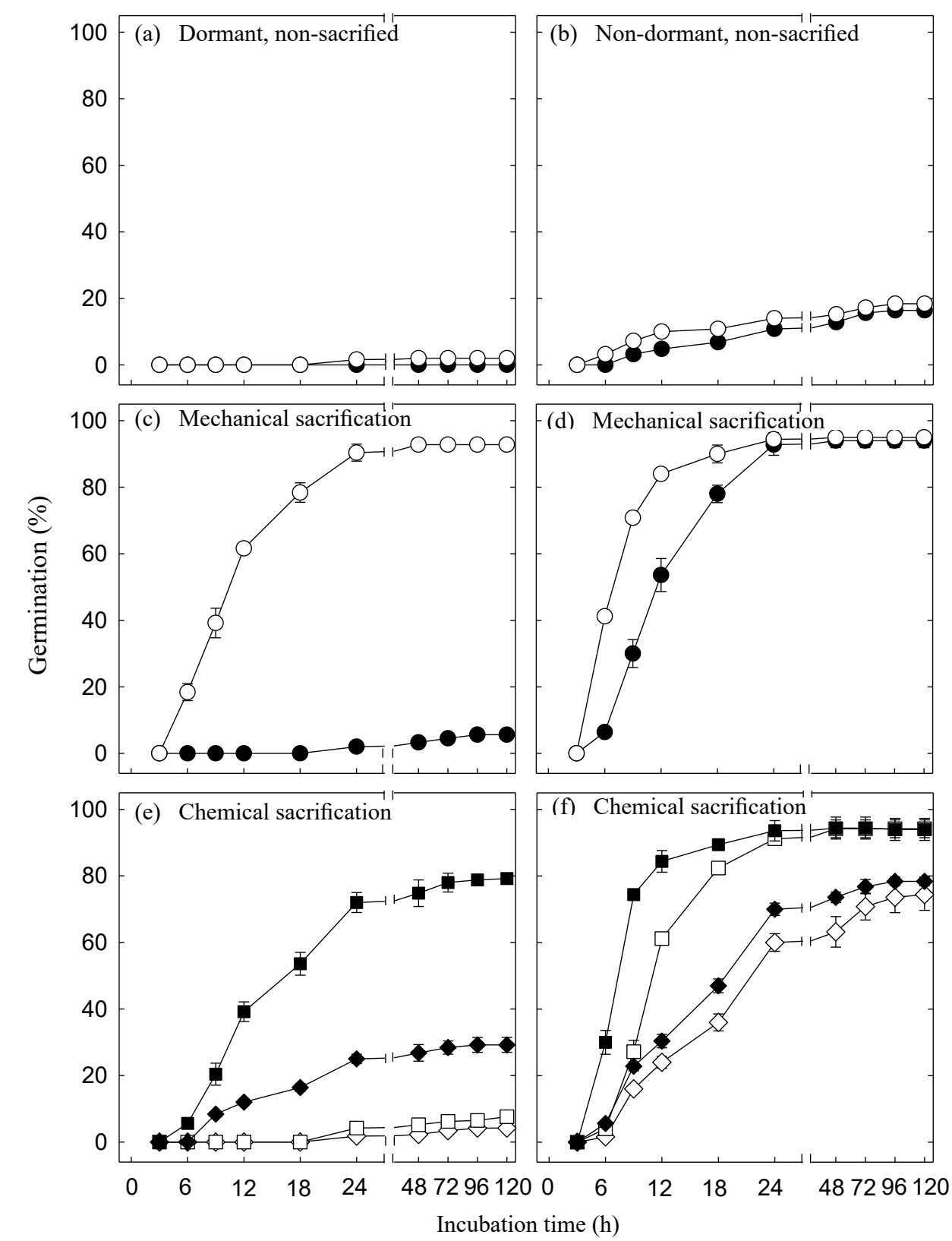

Figure 4. Time course of germination for dormant seed (15 post-harvest days old) and non-dormant seed (765 post-harvest days old) after pre-treatment with different physical dormancy breaking methods. (a, b, c and d) Seeds were imbibed in water (filled circle) or $1 \mathrm{mM} \mathrm{CEPA} \mathrm{(open} \mathrm{circle).} \mathrm{(e} \mathrm{and} \mathrm{f)} \mathrm{Seeds} \mathrm{were} \mathrm{pre-treated} \mathrm{with} \mathrm{H}_{2} \mathrm{SO}_{4}$ for 1 and 5 min, and imbibed in water (open diamond, open square) or $1 \mathrm{mM} \mathrm{CEPA} \mathrm{(filled} \mathrm{diamond,} \mathrm{filled} \mathrm{square),} \mathrm{respectively.} \mathrm{Data}$ points are means of five replicates \pm standard error.

hot, dry season in northern Australia. Soils in which species of Stylosanthes genus is distributed naturally are generally acidic (pH 4.0-5.5) (Williams et al., 1984), as the Cerrado (the Brazilian savannah) soils (Ruggiero et al., 2002). Low$\mathrm{pH}$ solutions were effective in overcoming physiological dormancy of scarified seeds of Townsville stylo (Pelacani et al., 2005a,b; Ribeiro et al., 2010). In the present work, those data were expanded to include the effects of low-pH solutions on physical dormancy overcome of Townsville stylo seeds (Figures 5a-d). Low pH of the incubation medium-mediated increase in the seed coat tetrazolium salt permeability during dormant and non-dormant seed imbibition (Figures 5a, b). The maximum significant effect induced by acidic solution occurred at $\mathrm{pH} 4.0$ when permeability of the dormant and 
non-dormant seeds to tetrazolium was increased by 2.1- and 2.3-fold, respectively, as compared with the control ( $\mathrm{pH} 7.0$ ) (Figures 5a, b). In line with this finding, acidic solutions increased germination of non-escarified seeds (Figures 5c, d, black bars). The maximum effect promoted by applied of low $\mathrm{pH}$ solutions occurred at $\mathrm{pH} 4.0$ when seed germination of dormant and non-dormant seeds was increased by 22.0- and 2.8-fold, respectively, as compared with the control ( $\mathrm{pH} 7.0$ ) (Figures 5c, d, black bars). The occurrence of germination indicates that the permeability to tetrazolium salt can be used to monitor the permeability of Townsville stylo seeds to water entry. As expected, physiological dormancy of scarified seeds was partially broken by acidic solution at $\mathrm{pH} 4.0$ and 5.0 (Figure 5c, white bars). In addition, low $\mathrm{pH}$ solutions had no toxic effect on the germination response of scarified non-dormant seeds (Figure $5 \mathrm{~d}$, white bars). In other words, freshly harvested seeds exhibited a reduced germination compared with non-dormant seeds, indicating that the germination behaviour of freshly harvested seeds treated with acid solutions is related to the degree of the physiological dormancy in the seeds. Together, these data indicate that low $\mathrm{pH}$ solutions causes seed coat weakening, which in turn may require a lower embryo force for its rupture.

\section{Conclusions}

Physical dormancy of Townsville stylo seed was not reduced during natural ageing at room temperature, in contrast to the physiological dormancy, which is gradually overcome during post-harvest ageing. Furthermore, the permeability of seed coat was affected by scarification treatments as well as by low-pH solutions, which leads to effects on germination. Given
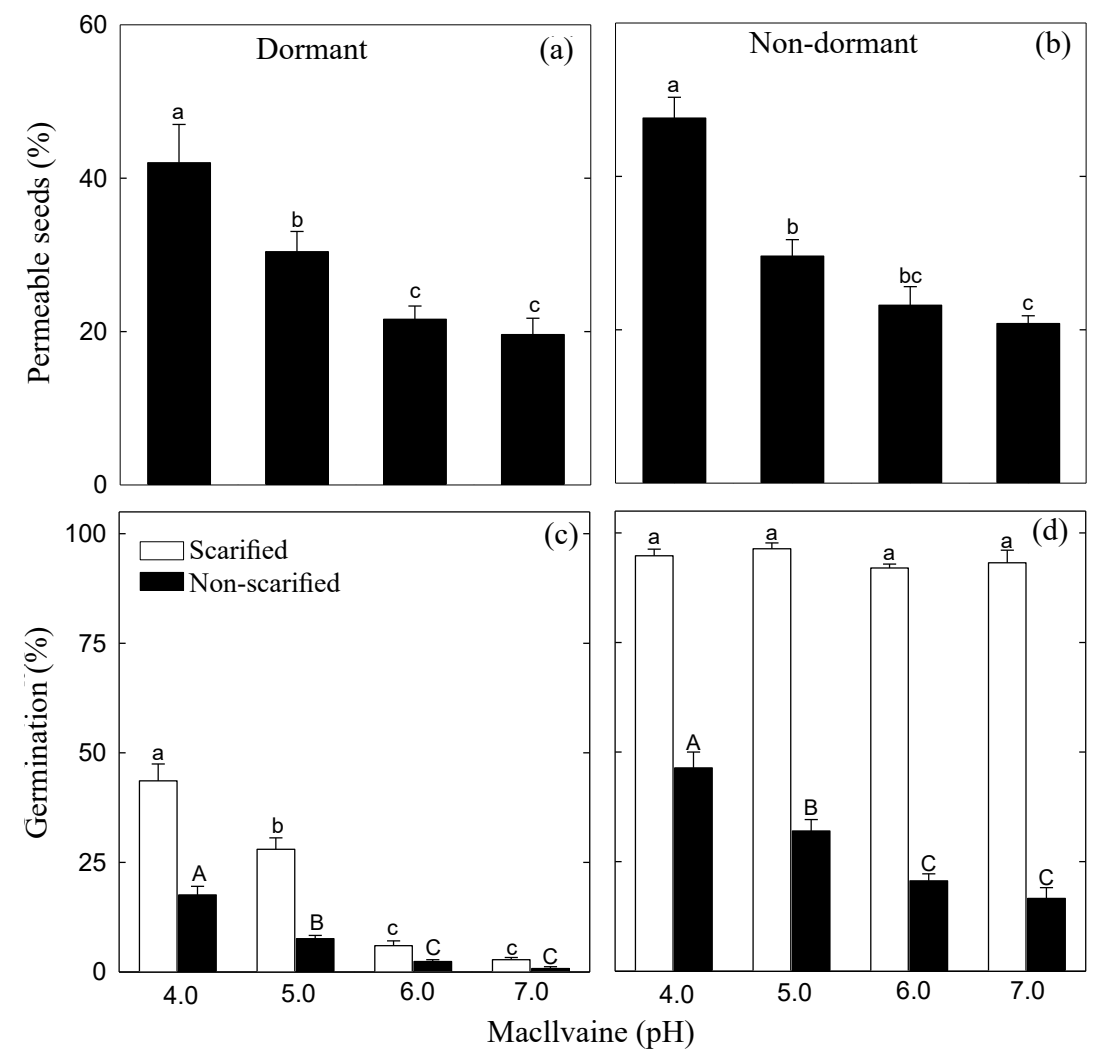

Figure 5. Response of Townsville stylo seeds to MacIlvaine buffer solutions at several pH(s). (a and b) Permeability of intact seed to tetrazolium salt supplied in MacIlvaine buffer at several $\mathrm{pH}(\mathrm{s})$. Remaining fraction of seed to $100 \%$ corresponds to impermeable seeds. (c and d) Germination of seeds incubated in serial pH MacIlvaine buffer solutions. Test-solutions were renewed 24 hours after start of imbibition. Permeability of seeds and germination were registered on the 5 th day. After mechanical scarification, permeability of seed coat to tetrazolium salt supplied in MacIlvaive pH 7.0 was $95 \pm 0.9 \%$ and $93 \pm 0.7 \%$ in dormant (15 post-harvest days old) and non-dormant seeds (765 post-harvest days old), respectively. Bars followed by the same small or capital letter across the range of MacIlvaine solutions do not differ statistically at the $5 \%$ level by Tukey test. 
that under treatment with acidic solutions a tight relationships linking seed coat permeability and germination are observed, it is possible that low $\mathrm{pH}$ soils would play an important ecological role in the successful establishment of Stylosanthes species population. In summary, seed coat weakening was a prerequisite for radicle protrusion and physiological dormancy of Townsville stylo seeds contribute to its timing.

\section{Acknowledgments}

Thanks are due to CAPES (Coordination for Scientific Support for Post-Graduate Level) for the scholarship awarded to D.M.R. The Brazilian Research Council (CNPq) is also acknowledged for the scholarship awarded to I.S.C. and for their financial support granted during the conduct of this research.

\section{References}

ANAND, A.; BHARDWAJ, J.; NAGARAJAN, S. Comparative evaluation of seed coat dorman breaking treatments in Stylosanthes seabrana. Grass and Forage Science, v.66, p.272-276, 2011. onlinelibrary. wiley.com/doi/10.1111/j.1365-2494.2011.00787.x/abstract

BATLLA, D.; BENECH-ARNOLD, R.L. Predicting changes in dormancy level in natural seed soil banks. Plant Molecular Biology, v.73, p.3-13, 2010. ncbi.nlm.nih.gov/pubmed/20091421

BASKIN, C.C.; BASKIN J.M. Seeds: ecology, biogeography, and evolution of dormancy and germination, 2ed. Elsevier, San Diego, CA, USA, 2014. 1600p.

BASKIN, J.M.; BASKIN, C.C. A classification system for seed dormancy. Seed Science Research, v.14, p.1-16, 2004. journals.cambridge.org/action/ displayAbstract?fromPage $=$ online $\&$ aid $=704528$

BENECH-ARNOLD, R.L.; SANCHEZ，R.A.; FORCELLA，F.; KRUK, B.C.; GHERSA, C.M. Environmental control of dormancy in weed seed banks in soil. Field Crops Research, v.67, p.105-122, 2000. sciencedirect.com/science/article/pii/S0378429000000873

BRIGGS, C.L.; MORRIS, E.C. Seed-coat dormancy in Grevillea linearifolia: little change in permeability to an apoplastic tracer after treatment with smoke and heat. Annals of Botany, v.101, p.623-632, 2008. aob.oxfordjournals.org/content/101/5/623.full

DEBEAUJON, I.; LÉON-KLOOSTERZIEL, K.M.; KOORNNEEF, $M$. Influence of the testa on seed dormancy, germination, and longevity in Arabidopsis. Plant Physiology, v.122, p.403-413, 2000. ncbi.nlm.nih.gov/pubmed/10677433

EDYE, L.A. Potential of Stylosanthes for improving tropical grasslands. Outlook on Agriculture, v.16, p.124-130, 1987. agris.fao. org/agris-search/search.do?recordID=US201302062481
GAMA-ARACHCHIGE, N.S.; BASKIN, J.M.; GENEVE, R.L.; BASKIN, C.C. The autumn effect: timing of physical dormancy break in seeds of two winter annual species of Geraniaceae by a stepwise process. Annals of Botany, v.110, p.637-651, 2012. aob. oxfordjournals.org/content/early/2012/06/08/aob.mcs122.full

GRIGG, A.; SHELTON, M.; MULLEN, B. The nature and management of rehabilitated pastures on open-cut coal mines in central Queensland. Tropical Grasslands, v.34, p.242-250, 2000. tropicalgrasslands.asn.au/Tropical\%20Grasslands\%20Journal\%20 archive/PDFs/Vol_34_2000/Vol_34_03-04_00_pp242_250.pdf

JAGANATHAN, G.K.; WU, G.R.; HAN, Y.Y.; LIU, BL. Role of lens in controlling physical dormancy break and germination of Delonix regia (Fabaceae: Casealpinioideae). Plant Biology, v.19, n.1, p.53-60, 2017. ncbi.nlm.nih.gov/pubmed/26998975

LINKIES, A.; MÜLLER, K.; MORRIS, K.; TUREČKOVÁ, V.; CADMAN, C.S.C.; CORBINEAU, F.; STRNAD, M.; LYNN, J.R.; FINCH-SAVAGE, W.E.; LEUBNER-METZGER, G. Ethylene interacts with abscisic acid to regulate endosperm rupture during germination: a comparative approach using Lepidium sativum and Arabidopsis thaliana. The Plant Cell, v.21, p.3803-3822, 2009. plantcell.org/content/21/12/3803.abstract

MCKEON, G.M.; MOTT, J.J. The effect of temperature on the field softening of hard seed of Stylosanthes humilis and S. hamata in a dry monsoonal climate. Australian Journal of Agricultural Research, v.33, p.75-85, 1982. publish.csiro.au/paper/AR9820075.htm

MOÏSE, J.A.; HAN, S.; GUDYNAITE-SAVITCH, L.; JOHNSON, M.B. Seed coats: structure, development, composition and biotechnology. In Vitro Cellular and Development BiologyPlant, v.41, p.620-644, 2005. link.springer.com/article/10.1079/ IVP2005686

MORRIS, K.; LINKIES, A.; MÜLLER, K.; ORACZ, K.; WANG, X.; LYNN, J.R.; LEUBNER-METZGER, G.; FINCH-SAVAGE, W.E. Regulation of seed germination in the close arabidopsis relative Lepidium sativum: A Global Tissue-Specific Transcript Analysis. Plant Physiology, v.155, n.4, p.1851-1870, 2011. plantphysiol.org/ content $/ 155 / 4 / 1851$.long

MOTT, J.J.; MCKEON, G.M. Effect of heat treatments in breaking hardseededness in four species of Stylosanthes. Seed Science and Technology, v.7, n.1, p.15-25, 1979. http://library.ciat.cgiar.org/cgibin/koha/opac-detail.pl?biblionumber $=68912 \&$ shelfbrowse_itemnu mber $=86536 \#$ shelfbrowser

MULLER, K.; LINKIES, A.; VREEBURG, R.A.M.; FRY, S.C.; KRIEGER-LISZKAY, A.; LEUBNER-METZGER, G. In Vivo cell wall loosening byhydroxyl radicals during cress seed germination and elongation growth. Plant Physiology, v.150, n.4, p.1855-1865, 2009. plantphysiol.org/content/150/4/1855.long

PAULA, A.S.; DELGADO, C.M.L.; PAULILO, M.T.S.; SANTOS, M. Breaking physical dormancy of Cassia leptophylla and Senna macranthera (Fabaceae: Casealpinioideae) seeds: water absorption and alternating temperatures. Seed Science Research, v.22, n.4, p.259-267, 2012. journals.cambridge.org/action/displayAbstract?fromPage $=$ online $\&$ aid $=8735812 \&$ fileId $=$ S096025851200013X 
PELACANI, C.R.; BARROS, R.S.; RIBEIRO, D.M.; FRIGERI R.B.C. Breaking dormancy of Stylosanthes humilis seeds with low pH solutions. Acta Physiologiae Plantarum, v.27, p.317-323, 2005 a. Link.springer.com/article/10.1007/s11738-005-0016-4

PELACANI, C.R.; RIBEIRO, D.M.; BARROS, R.S.; FRIGERI, R.B.C. Germination of dormant seeds of Stylosanthes humilis as affected by organic acids. Seed Science and Technology, v.33, n.1, p.105-113, 2005 b. ingentaconnect.com/content/ista/ sst/2005/00000033/00000001/art00011

PINHEIRO, F.J.A.; BARROS, R.S.; COELHO, T.G.; SOUZA, B.M.L. Breaking dormancy of Stylosanthes humilis seeds with selenium compounds. Seed Science Research, v.18, p.47-53, 2008. journals. cambridge.org/action/displayAbstract?fromPage $=$ online $\&$ aid $=1696060$

RIBEIRO, D.M.; BARROS, R.S. Sensitivity to ethylene as a major component in the germination of seeds of Stylosanthes humilis. Seed Science Research, v.16, p.37-45, 2006. journals.cambridge.org/ action/displayAbstract? fromPage $=$ online $\&$ aid $=705764$

RIBEIRO, D.M.; MAPELI, A.M.; CARNELOSSI, M.A.G.; DELATORRE, C.A.; BARROS, R.S. Dormancy breakage of Stylosanthes humilis seeds by aluminium. Seed Science Research, v.20, p.145-152, 2010. journals.cambridge.org/ action $/$ displayAbstract? fromPage $=$ online $\&$ aid $=7857428$

RIBEIRO, D.M.; MAPELI, A.M; DELATORRE, C.A.; CARNELOSSI, M.A.G.; BARROS, R.S. Action of ferric and aluminium ions on the dormancy breakage of Stylosanthes humilis seeds. Acta Physiologiae Plantarum, v.33, p.2117-2123, 2011. link. springer.com/article/10.1007\%2Fs11738-011-0750-8

RODRIGUES-JUNIOR， A.G.; FARIA， J.M.R.; VAZ， T.A.A.; NAKAMURA, A.T.; JOSE, A.C. Physical dormancy in Senna multijuga (Fabaceae: Caesalpinioideae) seeds: the role of seed structures in water uptake. Seed Science Research, v.24, n.2, p.147-157, 2014. journals. cambridge. org/action/displayAbstract?fromPage $=$ online \&aid $=9258135$

RUGGIERO, P.G.C.; BATALHA, M.A.; PIVELLO V.R.; TADEU MEIRELLES, S.T. Soil-vegetation relationships in cerrado (Brazilian savanna) and semideciduous forest, Southeastern Brazil. Plant Ecology, v.160, p.1-16, 2002. link-springer-com.ez35.periodicos. capes.gov.br/article/ 10.1023/A\%3A1015819219386

SANTOS-GARCIA, M.O.; TOLEDO-SILVA, G., SASSAKI, R.P.; FERREIRA, T.H.; RESENDE R.M.S.; CHIARI, L.; KARIA, C.T.; CARVALHO, M.A.; FALEIRO, F.B.; ZUCCHI, M.I.; SOUZA, A.P. Using genetic diversity information to establish core collections of Stylosanthes capitata and Stylosanthes macrocephala. Genetics and Molecular Biology, v.35, n.4, p.847-861, 2012. ncbi.nlm.nih. gov/pubmed/23271947
SMÝKAL, P.; VERNOUD, V.; BLAIR M.W.; SOUKUP, A.; THOMPSON R.D. The role of the testa during development and in establishment of dormancy of the legume seed. Frontiers in Plant Science, v.5, n.351, p.1-19, 2014. ncbi.nlm.nih.gov/pmc/articles/ PMC4102250/

STAPPEN, J.V.; WELTJENS, I.; LOPEZ, S.G.; VOLCKAERT, G. Genetic diversity in Mexican Stylosanthes humilis as revealed by AFLP, compared to the variability of $S$. humilis accessions of South American origin. Euphytica, v.113, p.145-154, 2000. link.springer. com/article/10.1023\%2FA\%3A1003989505449

STARR, C.R.; CORREA, R.S.; FILGUEIRAS, T.S.; HAY, J.D.V.; SANTOS, P.F. Plant colonization in a gravel mine revegetated with Sthyloshantes spp. in a Neotropical area savannah. Landscape and Ecological Engineering, v.9, n.1, p.189-201, 2013. link.springer. com/article/10.1007\%2Fs11355-012-0196-1

VAN KLINKEN, R.D.; FLACK, L.K.; PETTIT, W. Wet-season dormancy release in seed banks of a tropical leguminous shrub is determined by wet heat. Annals of Botany, v.98, p.875-883, 2006. aob.oxfordjournals.org/content/98/4/875.short

VAN SANDT, V.S.T.; SUSLOV, D.; VERBELEN, J.P.; VISSENBERG, K. Xyloglucan endotransglucosylase activity loosens a plant cell wall. Annals of Botany, v.100, p.1467-1473, 2007. ncbi.nlm.nih.gov/pmc/articles/PMC2759230/

VIEIRA, H.D.; BARROS, R.S. Response of seed of Stylosanthes humilis to germination regulators. Physiologia Plantarum, v.92, p.17-20, 1994. scielo.br/scielo.php?script=sci arttext\&pid=S1677-04202004000200003

WALCK, J.L.; BASKIN, J.M.; BASKIN, C.C.; HIDAYATI, S. Defining transient and persistent seed banks in species with pronounced seasonal dormancy and germination patterns. Seed Science Research, v.15, p.189-196, 2005. journals.cambridge.org/ action/displayAbstract?FromPage $=$ online \&aid $=705880$

WHARTON, M.J. The use of tetrazolium test for determining the viability of seeds of the genus Brassica. Proceedings of the International Seed Testing Association, v.20, p.81-88, 1955.

WILLIAMS, R.J.; REID, R.; SCHULTZE-KRAFT, R.; SOUZA COSTA, N.M.; THOMAS, B.D. Natural distribution of Stylosanthes. In: STACE, H.M.; EDYE, L.A. (Eds.) The biology and agronomy of Stylosanthes. Sydney: Academic Press, p.73-101, 1984. 